\title{
ANNUAL GROSS PRIMARY PRODUCTION AND ABSORPTION OF SOLAR ENERGY BY ARTEMISIA SP. IN ARID AND SEMIARID SHRUBLANDS
}

\author{
MOUSAEI SANJEREHEI, M. \\ Department of Plant Protection, Yazd Branch, Islamic Azad University, \\ Safayieh, Yazd, Iran \\ (phone: 00 983518211391) \\ *Corresponding author \\ e-mail:mmusaei@yahoo.com \\ (Received $15^{\text {th }}$ December 2012; accepted $2^{\text {nd }}$ September 2013)
}

\begin{abstract}
Gross primary production (GPP), transpiration and conversion efficiency of solar energy by Artemisia sieberi and Artemisia aucheri in Nodushan shrublands of Yazd, Iran, were determined. GPP was determined through estimates of net primary production (NPP) and respiration (R) of leaf, new branch, stem, coarse root and fine root. Total biomass $\left(\mathrm{g} \mathrm{C} \mathrm{m}^{-2}\right)$ of A.sieberi and A.aucheri was 81.7 and 224.87 respectively. The ratio of below-to-aboveground biomass was 0.4 and 0.56 respectively, for A.sieberi and A.aucheri. Total NPP, R and GPP $\left(\mathrm{g} \mathrm{C} \mathrm{m}^{-2}\right)$ were 32.11, 53.1 and 85.21 for A.sieberi and 62.75, 91.56 and 154.31 for A.aucheri. The carbon use efficiency (NPP/GPP), R/GPP and Belowground NPP/total NPP were $0.38,0.62$ and 0.29 for A.sieberi and $0.41,0.59$ and 0.37 for A.aucheri respectively. Based on the estimates of solar energy available in the study sites, the amount of incoming solar energy absorbed in photosynthesis and transpiration was $0.05 \%$ and $0.08 \%$ by A.sieberi, and $0.08 \%$ and $0.17 \%$ by A.aucheri. Artemisia shrublands play an important role as carbon sinks and energy stocks in arid and semiarid ecosystems of the central parts of Iran.
\end{abstract}

Keywords: Artemisia sieberi, Artemisia aucheri, Gross primary production, Solar energy, Transpiration

\section{Introduction}

Atmospheric $\mathrm{CO}_{2}$ concentration of twice the preindustrial level will lead to an increase in global mean temperature of $2.5^{\circ} \mathrm{C}$, which in turn may result in losses in the drylands, wetlands, species and ecosystems as well as major changes in agricultural, forestry and fishery sectors and an increase in water demand, air pollution and frequency of natural disasters (IPCC, 1990). Since the main source of absorbing $\mathrm{CO}_{2}$ is through photosynthesis by vegetation, the study of primary production seems to be of high importance. Estimates of primary production are useful for monitoring ecosystem goods and services (Meyerson et al., 2005), ecosystem function (Schlapfer and Schmid, 1999) and structure, providing resources for herbivores, evaluating the regulation of the global climate through the carbon cycles (Roy and Saugier, 2001), determining variation in wood production as well as studying energy flow in ecosystems (Roxburgh et al., 2004) and ecosystem carbon sequestration. The amount of energy fixed by plants in photosynthesis is referred to as gross primary production (GPP). Annual GPP is defined as the total of all carbon fixed by plants in ecosystems (Ryan, 1991). A portion of the $\mathrm{C}$ fixed, is lost through construction (growth) and maintenance respirations by plants. Construction respiration is the amount of $\mathrm{C}$ consumed in the processes such as ATP production, transport processes and nutrient uptake (Chiariello et al., 1989) which lead to a net increase in plant dry matter. Construction respiration can be estimated based on the heat of combustion, organic nitrogen and ash content (Williams et al., 
1987), carbon and ash content (Vertregt and Penning de Vries, 1987) or based on the assumption that it consumes carbon equal to $25 \%$ of that incorporated into new tissue (Ryan, 1991). Maintenance respiration provides the energy for the plant processes such as maintenance of ion gradients across membranes, protein repair and replacement and translocation-related processes (Penning de Vries, 1975) that do not result in a net gain in biomass, but keep existing phytomass in a healthy state (Amthor, 1989). Maintenance respiration can be calculated from tissue nitrogen and mean annual temperature (Ryan, 1991). The amount of $C$ allocated in plants in a certain period of time after losses due to respiration is known as net primary production (NPP). Another important source of solar energy use by plants is transpiration. Estimates of solar energy used in transpiration can be useful for the study of reduction in air temperature by vegetation through the conversion of solar energy to latent heat (Kurn et al., 1994). Based on increasing population growth and economic prosperity and as a result, a greater demand on production of food and fiber, improving solar energy conversion efficiency will be of critical importance. This requires a complete understanding of the amount of solar energy used by plants in different processes. The objective of this research was to determine (1) gross primary production and (2) the amount of energy absorbed in photosynthesis and transpiration by Artemisia sieberi and Artemisia aucheri in Nodushan rangelands of Yazd. A.sieberi and A.aucheri are the most dominant species in Nodushan rangelands of Yazd. These species are two of the most distributed perennial shrubs in central parts of Iran.

\section{Materials and Methods}

\section{Site description}

NPP, respiration, GPP, transpiration and the amount of solar energy captured by Artemisia sieberi and Artemisia aucheri species were determined in Nodushan rangelands of Yazd, Iran. Nodushan rangelands are located in the northwest of Yazd province in central parts of Iran $\left(31^{\circ} 46^{\prime} \mathrm{N}, 52^{\circ} 24^{\prime} \mathrm{E}\right.$ to $\left.32^{\circ} 15^{\prime} \mathrm{N}, 53^{\circ} 47^{\prime} \mathrm{E}\right)$ at elevations between $1530 \mathrm{~m}$ and $3260 \mathrm{~m}$. Two sites were selected in Nodushan rangelands for sampling. (1) Sadrabad area which is located at an elevation of $2171 \mathrm{~m}$ and is dominated by A.sieberi (Figure 1). The climate is characterized as arid. The mean annual precipitation and temperature are $89 \mathrm{~mm}$ and $13.5{ }^{\circ} \mathrm{C}$ respectively. (2) Khood area which is located at an elevation of $2525 \mathrm{~m}$ and is dominated by A.aucheri (Figure 1). The climate is semiarid. The mean annual precipitation and temperature are $123 \mathrm{~mm}$ and $11{ }^{\circ} \mathrm{C}$ respectively. The growing season of A.sieberi and A.aucheri is from early March to mid November, about 260 days. Data of rainfall, temperature, humidity and duration of sunshine on 2011 were collected from synoptic station of Nodushan, Meybod. 

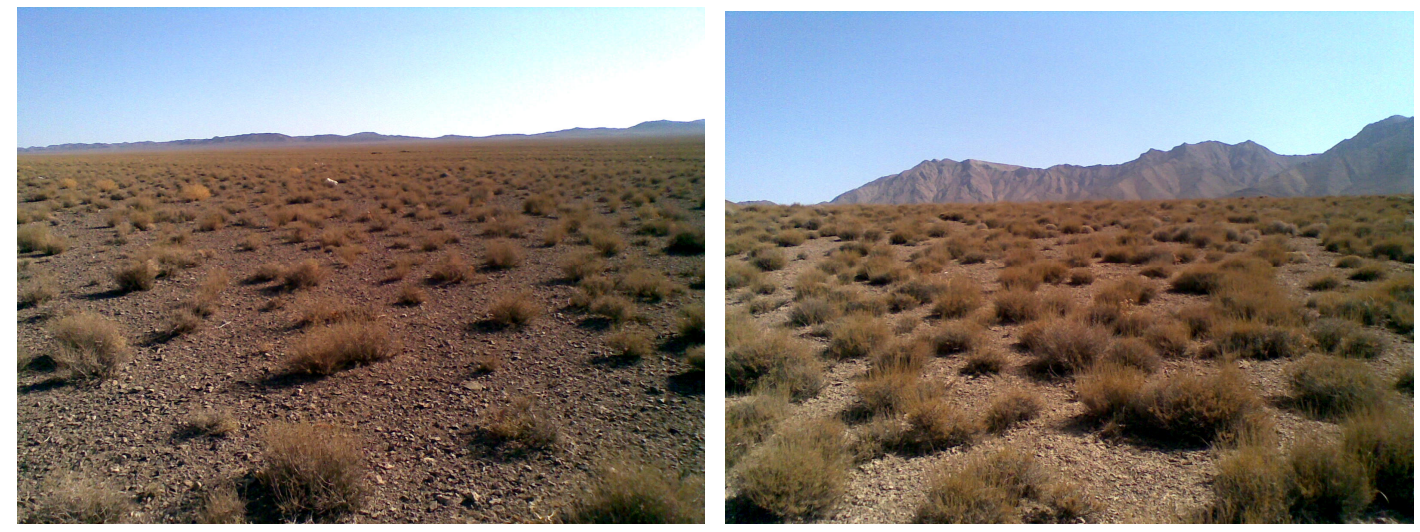

Figure 1. Artemisia sieberi stand in Sadrabad site (left) and Artemisia aucheri stand in Khood site (right)

\section{Preparation of plant samples}

To estimate the above and belowground production, 6 individuals of each species with different sizes were totally (shoot and root) harvested every 2 months during the growing season (Figure 2). The total biomass was separated into leaf, new and old branch, stem, coarse root (diameter $>2 \mathrm{~mm}$ ) and fine root $(<2 \mathrm{~mm})$. Leaf area index was estimated by measuring the area and the weight of a number of leaves and determination of a relationship between leaf area and leaf weight.
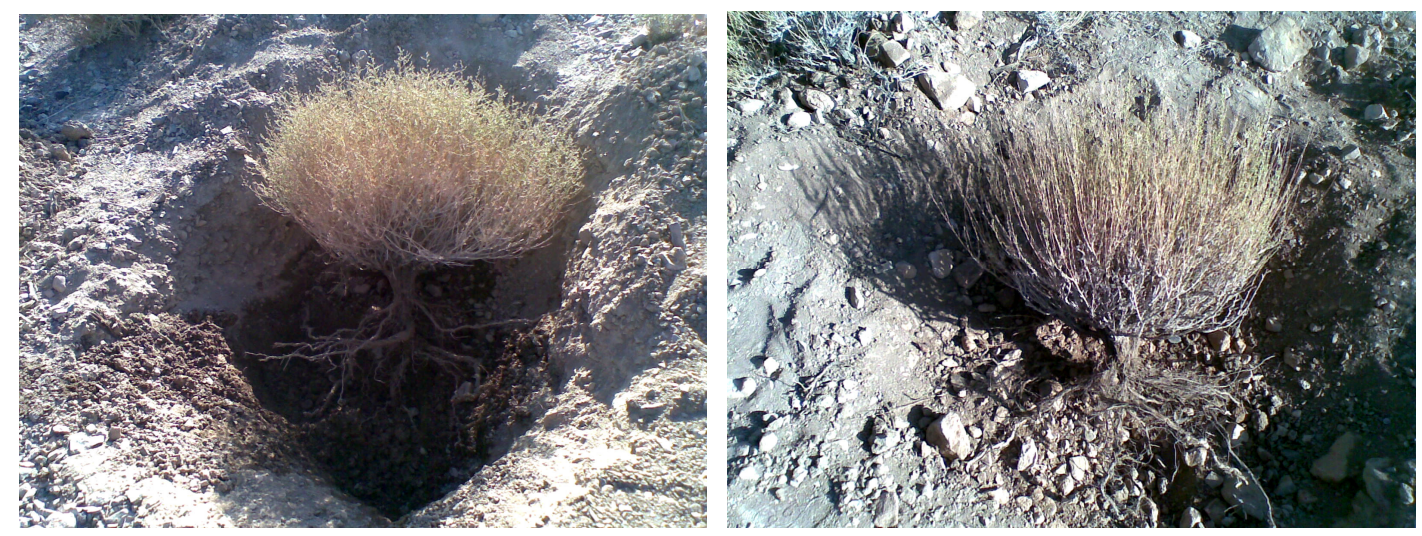

Figure 2. Harvesting the whole plant, Artemisia sieberi (left) and Artemisia aucheri (right)

A total of 10 soil cores were collected randomly below the canopy cover of A.sieberi and A.aucheri with an auger (10 cm diameter) at a depth of $30 \mathrm{~cm}$ (based on the depth of plant rooting) at 2 month intervals during the growing season to determine the fine root production. Dead and live fine roots were separated based on their shape, color and flexibility. To estimate the stem annual growth, 3 plants with different sizes were selected for each species, and the diameter and the length of 5 stems with different sizes for each plant were measured at the beginning and at the end of the growing season. 2 points on each selected stem were wrapped with a piece of metal wire for measuring the diameter and the length. The stems were marked with plastic tags. The annual growth of the stems was determined based on the annual increment in the volume of the sampling 
stems and its equivalent weight. The density and the cover of plants were estimated using 40 randomly located $1 \times 2 \mathrm{~m}^{2}$ quadrats.

\section{Measurement of composition of plant components}

Plant components (leaf, new branch, old branch, stem, coarse root and fine root) were dried in oven at $70{ }^{\circ} \mathrm{C}$ for $48 \mathrm{~h}$. Nitrogen content was measured by the Kjeldahl method. Carbon content was estimated with an elemental analyzer (Costech ECS 4010, Elemental Combustion System). Ash content was determined after heating the dry matter to $550{ }^{\circ} \mathrm{C}$ for 5 hours.

\section{Total net primary production (Total NPP)}

Total NPP (g Carbon $\mathrm{m}^{-2}$ ) was determined as the sum of the aboveground net primary production (ANPP) and the belowground net primary production (BNPP). ANPP was calculated as the sum of the leaf production and wood production. Maximum value of leaf biomass during the growing season was used as the leaf production. Wood production was considered as the sum of the biomass of new branches at the time of maximum growth and annual increment in the stem biomass. BNPP was determined by measuring coarse root production and fine root production. Coarse root production $\left(N P P_{c r}\right)$ was calculated using an equation which assumes that coarse root production is proportional to aboveground NPP (Johnson and Risser, 1974).

$$
N P P_{c r}=\frac{A N P P}{A G B} \times B_{c r}
$$

Where $N P P_{c r}$ is coarse root production, ANPP is aboveground net primary production, AGB is aboveground biomass and $B_{c r}$ is coarse root biomass (at the time of maximum growth). Fine root production $\left(N P P_{f r}\right)$ was estimated as differences in means of fine root biomass between sampling dates. Positive biomass increments were summed during the growing season (Fogel, 1983). Fine root biomass $\left(\mathrm{g} \mathrm{C} \mathrm{m}^{-2}\right)$ was calculated according to the following Equation.

$$
B_{f r}=\left[\frac{\text { Mean weight of fine root per core }}{\pi(10)^{2} / 4}\right] \times(\text { Percent rooting cover })
$$

Since the study sites are not totally covered by the plants, and the sampling cores were taken below the canopy cover of the plants, the mean weight of fine root biomass per square was multiplied by the area $(\%)$ covered by the plant roots.

\section{Total respiration (Total $R)$}

Total respiration was calculated as the sum of maintenance $\left(R_{m}\right)$ and construction $\left(R_{c}\right)$ respiration. Construction respiration was determined as:

$$
R_{c}=R_{c l}+R_{c w}+R_{c c r}+R_{c f r}
$$


Where $R_{c l}, R_{c w}, R_{c c r}$ and $R_{c f r}$ are respectively, the construction respiration of leaf production, wood production (new branches and increased annual biomass of stems) and coarse root and fine root production. Construction respiration was determined using carbon, nitrogen and ash content of plant materials based on Vertregt and Penning de Vries (1987) method slightly modified by Poorter (1994).

$$
R_{c}=\left(-1.041+5.077 C_{o m}\right)(1-M)+\left(5.235 N_{o r g}\right)
$$

Where $R_{c}$ is the construction cost ( $\mathrm{g}$ glucose $\mathrm{g}^{-1}$ dry weight), $C_{o m}$ is the carbon content of the organic material $\left(\mathrm{g} \mathrm{g}^{-1}\right)$, and $M$ and $N_{\text {org }}$ are the mineral (ash content) and organic $\mathrm{N}$ concentration of the total dry matter $\left(\mathrm{g} \mathrm{g}^{-1}\right)$. The carbon equivalent of the glucose used in respiration can be calculated based on the atomic weight of carbon and glucose $\left(\mathrm{C}_{6} / \mathrm{C}_{6} \mathrm{H}_{12} \mathrm{O}_{6}=72 / 180\right)$. Construction respiration is then, equal to the total carbon cost minus carbon incorporated into structure. Maintenance respiration was determined as:

$$
R_{m}=R_{m l}+R_{m s w}+R_{m f r}
$$

Where $R_{m l}, R_{m s w}$ and $R_{m f r}$ are maintenance respiration of leaf production, sapwood and fine root production respectively. $R_{m l}$ and $R_{m f r}$ were determined using Ryan's (1991) equation,

$$
R_{m}^{*}=N_{t} \times D \times 0.059 \times \exp \left(0.07 T_{a}\right)
$$

Where $T_{a}$ is the average growing season temperature $\left({ }^{\circ} \mathrm{C}\right)$ and $D$ is duration of growing season (number of days). For estimation of $R_{m l}, N_{t}$ is the total nitrogen content of leaf biomass calculated from $N$ concentration in leaf biomass and average leaf biomass during the growing season (the average leaf biomass was used in the calculation, because the rate of production is low at the beginning of the growing season, March, and peaks around July, then decreases towards the end of the growing season, November). For determination of $R_{m f r}, N_{t}$ is the total $\mathrm{N}$ in fine root biomass calculated from $N$ concentration and average fine root production during the growing season. New branches and coarse roots (diameter $>2 \mathrm{~mm}$ ) were assumed to be $100 \%$ of sapwood (Ryan and Waring, 1992). The stem sapwood was determined by separating the bark of a number of stems with different sizes and recognizing the sapwood based on the color. Maintenance respiration of new branches was also obtained using the equation $R_{m}^{*}$, based on the $N$ content in the new branch biomass (sapwood) and the average of new branch biomass during the growing season. Maintenance respiration of coarse roots and stems was determined as (Ryan, 1991):

$$
R_{m}=N_{s w} \times 27 \times \exp \left(0.07 T_{a}\right)
$$


Where $T_{a}$ is average annual temperature $\left({ }^{\circ} \mathrm{C}\right)$ and $N_{s w}$ is $N$ content in sapwood calculated from sapwood biomass and sapwood $N$ concentration.

\section{Gross primary production (GPP)}

Annual GPP was calculated from the total net primary production plus the total respiration.

\section{Solar energy capture}

The amount of solar energy used by plants was determined as the sum of the energy fixed as GPP and the energy consumed in transpiration. The energy fixed as GPP was determined based on the glucose equivalent of the carbon fixed in plants as GPP $\left(\mathrm{C}_{6} / \mathrm{C}_{6} \mathrm{H}_{12} \mathrm{O}_{6}=72 / 180\right)$ and the energy required to produce glucose (3740 Cal $\mathrm{gr}^{-1}$ glucose ).

\section{Energy Used in Transpiration}

The amount of energy used in transpiration was determined from the amount of water transpired by Artemisia species in the growing season and the amount of energy required for evaporating water at the mean temperature of the growing season. The energy necessary to evaporate water at the mean temperature during the growing season was calculated from Harrison' (1963) equation:

$$
\lambda_{v}=597.3-0.564 T
$$

Where $\lambda_{v}$ is the latent heat of vaporization $\left(\mathrm{Cal} \mathrm{g}^{-1}\right)$ and $T$ is the mean temperature in the growing season $\left({ }^{\circ} \mathrm{C}\right)$. Transpiration $\left(T_{R}\right)$ was estimated by partitioning evapotranspiration into evaporation and transpiration following the approach of Campbell (1985):

$$
T_{R}=A E T[1-\exp (-0.82 F)]
$$

Where AET is actual evapotranspiration and $F$ is leaf area index. Actual evapotranspiration $(\mathrm{mm})$ during the growing season was estimated according to Schreiber's (1904) empirical formula:

$$
A E T=P-\exp \left(\frac{P E T}{P}\right)
$$

Where $P$ is mean annual precipitation $(\mathrm{mm})$ and $P E T$ is potential evepotranspiration $(\mathrm{mm})$ during the growing season obtained from Thornthwaite's (1948) method.

$$
P E T=16\left(\frac{L}{12}\right)\left(\frac{N}{30}\right)\left[\frac{10 T}{I}\right]^{a}
$$


Where $T$ :average monthly temperature $\left({ }^{\circ} \mathrm{C}\right)$ from March to November, $L$ : the average day length (hours) of the month, $N$ : the number of days in the month and $I$ : the heat index calculated as:

$$
I=\sum_{t=1}^{n}\left[\frac{T_{i}}{5}\right]^{1.514}
$$

Where $T_{i}$ : average monthly temperature. $a$ is calculated from:

$$
a=0.49239+0.0179 I-0.0000771 I^{2}+0.000000675 I^{3}
$$

\section{Determination of solar radiation}

To estimate the percentage of the energy used by plants in photosynthesis and transpiration, the annual incoming solar radiation and the net solar radiation were determined. Net radiation $\left(R_{n}, \mathrm{MJ} \mathrm{m}^{-2} \mathrm{day}^{-1}\right)$ was estimated by the following equations (see FAO, Irrigation and drainage paper, Allen et al., 1998).

$$
R_{n}=R_{n s}-R_{n l}
$$

Where $R_{n s}$ : incoming net shortwave radiation and $R_{n l}$ : outgoing net longwave radiation $\left(\mathrm{MJ} \mathrm{m}^{-2} \mathrm{day}^{-1}\right)$.

$$
R_{n s}=(1-\alpha) R_{s}
$$

Where $\alpha$ : albedo or canopy reflection coefficient $(0.23)$ and $R_{s}$ : incoming solar radiation $\left(\mathrm{MJ} \mathrm{m}^{-2} \mathrm{day}^{-1}\right)$.

$$
R_{s}=\left[0.25+0.5\left(\frac{n}{N}\right)\right] \times R_{a}
$$

Where $n$ : actual duration of sunshine (hour), $N$ : maximum possible duration of sunshine or daylight hours (hour) obtained from:

$$
N=\frac{24 \omega_{s}}{\pi}
$$

Where $\omega_{s}$ : sunset hour angle.

$$
\omega_{s}=\arccos [-\tan (\varphi) \tan (\delta)]
$$

Where $\varphi$ : latitude (rad) and $\delta:$ solar decimation (rad). 


$$
\delta=0.409 \sin \left(\frac{2 \pi}{365} J-1.39\right)
$$

Where $J$ is the number of the day in the year between 1 ( 1 January) and 365 or 366 (31 December) and $R_{a}$ : extraterrestrial radiation $\left(\mathrm{MJ} \mathrm{m}^{-2} \mathrm{day}^{-1}\right)$ :

$$
R_{a}=\frac{24(60)}{\pi} G_{s c} d_{r}\left[\omega_{s} \sin (\varphi) \sin (\delta)+\cos (\varphi) \cos (\delta) \sin \left(\omega_{s}\right)\right]
$$

Where $G_{s c}$ : solar constant $\left(0.082 \mathrm{MJ} \mathrm{m}^{-2} \mathrm{~min}^{-1}\right), d_{r}$ : inverse relative distance earthsun.

$$
d_{r}=1+0.033 \cos \left(\frac{2 \pi}{365} J\right)
$$

The Outgoing net longwave radiation was determined as:

$$
R_{n l}=\sigma\left[\frac{T_{\max , K}^{4}+T_{\min , K}^{4}}{2}\right]\left(0.34-0.14 \sqrt{e_{a}}\right)\left(1.35 \frac{R_{s}}{R_{s o}}-0.35\right)
$$

Where $\sigma$ : Stefan-Boltzmann constant $\left(4.903 \times 10^{-9} \mathrm{MJ} \mathrm{K}^{-4} \mathrm{~m}^{-2} \mathrm{day}^{-1}\right), T_{\max , K}$ and $T_{\min , k}$ are daily maximum and minimum absolute temperature $\left({ }^{\circ} K\right)$ respectively, $e_{a}$ : actual vapor pressure $(\mathrm{kPa})$,

$$
e_{a}=0.611 \exp \left(\frac{17.27 T}{237.3+T}\right) \times R H
$$

where $T$ : mean daily temperature $\left({ }^{\circ} \mathrm{C}\right)$ and $R H$ : relative humidity. $R_{s o}$ : clear-sky solar radiation.

$$
R_{s o}=\left(0.75+2 \times 10^{-5} z\right) \times R_{a}
$$

Where $z$ : elevation above sea level (m).

\section{Results}

\section{Incoming and net solar radiation}

Based on the calculations, the annual incoming solar radiation $\left(R_{s}\right)$ and the net solar radiation $\left(R_{n}\right)$ were respectively, $1.7045 \times 10^{10} \mathrm{kcal} \mathrm{ha}^{-1}\left(467 \mathrm{Cal} \mathrm{cm}^{-2} \mathrm{day}^{-1}\right)$ and $7.807 \times 10^{9} \mathrm{kcal} \mathrm{ha}^{-1}\left(213.9 \mathrm{Cal} \mathrm{cm}^{-2} \mathrm{day}^{-1}\right)$ in A.sieberi stand and $1.7064 \times 10^{10} \mathrm{kcal}$ $\mathrm{ha}^{-1}\left(467.5 \mathrm{Cal} \mathrm{cm}^{-2} \mathrm{day}^{-1}\right)$ and $7.944 \times 10^{9} \mathrm{kcal} \mathrm{ha}^{-1}\left(217.6 \mathrm{Cal} \mathrm{cm}^{-2} \mathrm{day}^{-1}\right)$ in A.aucheri stand. 


\section{Chemical composition}

The carbon, nitrogen and ash content in the biomass of plant components for A.sieberi and A.aucheri are presented in Table 1.

Table 1. Percentage of the carbon, nitrogen and ash in the biomass of A.sieberi and A.aucheri components

\begin{tabular}{c|c|c|c|c|c}
\hline A.sieberi & Leaf & New branch & Stem & Coarse root & Fine root \\
\hline Carbon & 48.1 & 47.4 & 46.2 & 47.3 & 45.1 \\
Nitrogen & 1.9 & 1.1 & 1.1 & 0.7 & 0.9 \\
Ash & 9.5 & 4.6 & 6.5 & 5.6 & 10 \\
\hline A.aucheri & & & & & \\
\hline Carbon & 50.7 & 47.8 & 45.4 & 47.8 & 47.2 \\
Nitrogen & 1.4 & 0.7 & 0.7 & 0.6 & 0.7 \\
Ash & 7.4 & 5 & 6.1 & 4.9 & 8 \\
\hline
\end{tabular}

\section{Vegetation biomass}

The density and the cover of A.sieberi were 0.6 (number $\mathrm{m}^{-2}$ ) and $10 \%$ respectively. The average dry weight of an A.sieberi plant was $291.2 \mathrm{~g}$ (total biomass of $174.7 \mathrm{~g}$ dry matter $\mathrm{m}^{-2}$ regarding the density) (Table 2). The average dry matter of leaf, new branch, old branch, stem, coarse root and fine root biomass of an A.sieberi plant was $20.5 \mathrm{~g}$ (biomass of $\left.12.3 \mathrm{gm}^{-2}\right), 49.1 \mathrm{~g}\left(29.46 \mathrm{gm}^{-2}\right), 60.62 \mathrm{~g}\left(36.37 \mathrm{gm}^{-2}\right), 77.96 \mathrm{~g}\left(46.78 \mathrm{gm}^{-2}\right)$,

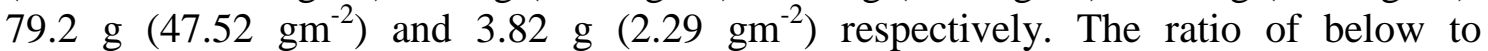
aboveground biomass for an A.sieberi plant was 0.4 (range of 0.29-0.53). The density and the cover of A.aucheri were 1 (number $\mathrm{m}^{-2}$ ) and $20.5 \%$ respectively. The average dry matter of an A.aucheri plant was estimated to be $483.2 \mathrm{~g}$ (total biomass of $483.2 \mathrm{~g} \mathrm{~m}^{-}$ ${ }^{2}$ ) The average dry matter of leaf, new branch, old branch, stem, coarse root and fine root biomass of an A.aucheri plant was $14.8 \mathrm{~g}$ (total leaf biomass of $14.8 \mathrm{~g} \mathrm{~m}^{-2}$ ), $30.6 \mathrm{~g}$ $\left(30.6 \mathrm{~g} \mathrm{~m}^{-2}\right), 53.5 \mathrm{~g}\left(53.5 \mathrm{gm}^{-2}\right), 210 \mathrm{~g}\left(210 \mathrm{gm}^{-2}\right), 167.9 \mathrm{~g}\left(167.9 \mathrm{gm}^{-2}\right), 6.4 \mathrm{~g}\left(6.4 \mathrm{gm}^{-2}\right)$ (Table 2). The ratio of below to aboveground biomass was $0.56(0.38-0.77)$ for an A.aucheri plant.

\section{Net primary production}

Total above and belowground biomass $\left(\mathrm{g} \mathrm{C} \mathrm{m}^{-2}\right)$ of A.sieberi was 58.2 and 23.5 respectively (81.7) (Table 2). The total above and belowground NPP $\left(\mathrm{g} \mathrm{C} \mathrm{m}^{-2}\right)$ of A.sieberi was 22.88 (27\% of GPP and $71 \%$ of total NPP) and 9.23 (11\% of GPP and $29 \%$ of total NPP) respectively (total NPP: $32.11 \mathrm{~g} \mathrm{C} \mathrm{m}^{-2}: 38 \%$ of GPP). The leaf, new branch, stem, coarse root and fine root NPP $\left(\mathrm{g} \mathrm{C} \mathrm{m}^{-2}\right)$ of A.sieberi during the growing season were 5.92, 13.96, 3, 8.82 and 0.41 . Total above and belowground biomass ( $\mathrm{g} \mathrm{C}$ $\mathrm{m}^{-2}$ ) of A.aucheri was estimated to be 141.6 and 83.28 respectively (224.88). The leaf, new branch, stem, coarse root and fine root NPP $\left(\mathrm{g} \mathrm{C} \mathrm{m}^{-2}\right)$ of A.aucheri were 7.5, 14.63, 17.4, 22.38 and 0.84 respectively, during the growing season. The total above and belowground NPP $\left(\mathrm{g} \mathrm{C} \mathrm{m}^{-2}\right.$ ) of A.aucheri was 39.53 (26\% of GPP and $0.63 \%$ of total 
NPP) and 23.22 (15\% of GPP and 37\% of total NPP) respectively (total NPP: $62.75 \mathrm{~g} \mathrm{C}$ $\mathrm{m}^{-2}: 41 \%$ of GPP).

Table 2. Biomass, net and gross primary production and respiration of A.sieberi and A.aucheri in the study stands

\begin{tabular}{|c|c|c|c|c|c|c|c|c|c|c|c|c|}
\hline \multicolumn{7}{|c|}{ Artemisia sieberi } & \multicolumn{6}{|c|}{ Artemisia aucheri } \\
\hline & Leaf & $\begin{array}{c}\text { New } \\
\text { branch }\end{array}$ & Stem & $\begin{array}{c}\text { Coarse } \\
\text { root }\end{array}$ & $\begin{array}{l}\text { Fine } \\
\text { root }\end{array}$ & Total & Leaf & $\begin{array}{c}\text { New } \\
\text { branch }\end{array}$ & Stem & $\begin{array}{c}\text { Coarse } \\
\text { root }\end{array}$ & $\begin{array}{l}\text { Fine } \\
\text { root }\end{array}$ & Total \\
\hline $\begin{array}{l}\text { Aver. } \\
\text { biomass of } \\
\text { an indiv. } \\
\text { (g DM) }\end{array}$ & 20.5 & 49.1 & 77.96 & 79.2 & 3.82 & $291.2 *$ & 14.8 & 30.6 & 210 & 167.9 & 6.4 & $483.2 *$ \\
\hline $\begin{array}{l}\text { Biomass } \\
\left(\mathrm{gDMm}^{-2}\right)\end{array}$ & 12.3 & 29.46 & 46.78 & 47.52 & 2.29 & $174.72 *$ & 14.8 & 30.6 & 210 & 167.9 & 6.4 & $483.2 *$ \\
\hline $\begin{array}{l}\mathrm{NPP} \\
\left(\mathrm{gCm}^{-2}\right)\end{array}$ & 5.92 & 13.96 & 3 & 8.82 & 0.41 & 32.11 & 7.5 & 14.63 & 17.4 & 22.38 & 0.84 & 62.75 \\
\hline $\mathrm{Rc}\left(\mathrm{gCm}^{-2}\right)$ & 0.82 & 2.08 & 0.32 & 1.03 & 0.016 & 4.27 & 1.34 & 1.94 & 1.35 & 2.9 & 0.074 & 7.6 \\
\hline $\mathrm{Rm}\left(\mathrm{gCm}^{-2}\right)$ & 8.9 & 12.1 & 3.7 & 23.1 & 1.03 & 48.83 & 6.05 & 6.25 & 11 & 58.75 & 1.91 & 83.96 \\
\hline NPP/GPP & 0.38 & 0.5 & 0.43 & 0.27 & 0.28 & 0.38 & 0.5 & 0.64 & 0.58 & 0.27 & 0.3 & 0.41 \\
\hline $\begin{array}{l}\text { Total } \\
\text { R/GPP }\end{array}$ & 0.62 & 0.5 & 0.57 & 0.73 & 0.72 & 0.62 & 0.5 & 0.36 & 0.42 & 0.73 & 0.70 & 0.59 \\
\hline $\begin{array}{l}\text { ANPP } \\
\left(\mathrm{gCm}^{-2}\right)\end{array}$ & 22.88 & & & & & & & & 39.53 & & & \\
\hline $\begin{array}{l}\text { ANPP/Total } \\
\text { NPP }\end{array}$ & 0.71 & & & & & & & & 0.63 & & & \\
\hline ANPP/GPP & 0.27 & & & & & & & & 0.26 & & & \\
\hline $\begin{array}{l}\mathrm{BNPP} \\
\left(\mathrm{gCm}^{-2}\right)\end{array}$ & & & & 9.23 & & & & & & & 23.22 & \\
\hline $\begin{array}{l}\text { BNPP/Total } \\
\text { NPP }\end{array}$ & & & & 0.29 & & & & & & & 0.37 & \\
\hline
\end{tabular}

*: Values of biomass for old branches are not presented in table 2, but the total values for biomass are shown regarding the values for old branches (see the text). For A.sieberi and A.aucheri, the average dry matter of old branches for an individual plant was $60.62 \mathrm{~g}$ and $53.5 \mathrm{~g}$, and biomass of old branches was

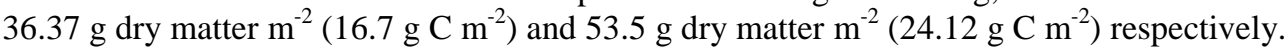

\section{Construction and maintenance respiration}

For A.sieberi, the construction respiration was $4.27 \mathrm{~g} \mathrm{C} \mathrm{m}^{-2}$ (Table 2). This was equal to $5 \%$ of GPP. The construction respiration of A.aucheri was $7.6 \mathrm{~g} \mathrm{C} \mathrm{m}^{-2}$ (4.9\% of GPP). The annual maintenance respiration of A.sieberi biomass was $48.83 \mathrm{~g} \mathrm{C} \mathrm{m}^{-2}(57 \%$ of GPP). The annual maintenance respiration of A.aucheri biomass was $83.96 \mathrm{~g} \mathrm{C} \mathrm{m}^{-2}$ (54\% of GPP). $10.36 \%$ of stem biomass of A.sieberi and $12.83 \%$ of stem biomass of A.aucheri was composed of sapwood. Total respiration was $62 \%$ and $59 \%$ of GPP for A.sieberi and A.aucheri respectively.

\section{Gross primary production and conversion efficiency of solar energy to GPP}

The annual GPP $\left(\mathrm{g} \mathrm{C} \mathrm{m}^{-2}\right)$ of A.sieberi and A.aucheri was estimated to be 85.21 and 154.31 respectively (Table 2 ). The energy necessary to produce the glucose equivalent of this amount of carbon is 796.7 and $1442.8 \mathrm{kcal} \mathrm{m}^{-2} \mathrm{yr}^{-1}$ for the two species 
respectively. Therefore, the conversion efficiency of the annual incoming solar energy $\left(R_{\text {inco } \min g}\right)$ and net solar energy $\left(R_{\text {net }}\right)$ to GPP was $0.047 \%$ and $0.1 \%$ by A.sieberi, and $0.084 \%$ and $0.18 \%$ by A.aucheri respectively.

\section{Energy used in transpiration}

Actual evapotranspiration during the growing season was estimated $88.97 \mathrm{~mm}$ and $122.3 \mathrm{~mm}$ for A.sieberi and A.aucheri stands, respectively. The relationship between the leaf weight and the leaf area was found to be as $1 \mathrm{~g}=28 \mathrm{~cm}^{-2}$ for A.sieberi and $1 \mathrm{~g}=$ $32.9 \mathrm{~cm}^{-2}$ for A.aucheri. Based on the leaf biomass of the species, leaf area index (LAI) of A.sieberi and A.aucheri was determined as 0.034 and 0.049 respectively. The rate of transpiration (Kg water) of A.sieberi and A.aucheri was estimated $24500 \mathrm{~kg} \mathrm{ha}^{-1}$ and $48000 \mathrm{~kg} \mathrm{ha}^{-1}$ during the growing season using the evapotranspiration and LAI. Based of the energy necessary to evaporate water in A.sieberi site $\left(587.8 \mathrm{Cal} \mathrm{gr}^{-1}\right.$ water) and A.aucheri site $\left(589.2 \mathrm{Cal} \mathrm{gr}^{-1}\right.$ water), the amount of energy used in transpiration was $1440 \mathrm{kcal} \mathrm{m}^{-2}\left(0.08 \%\right.$ of the $\mathrm{R}_{\text {incoming }}$ and $0.18 \%$ of the $\left.\mathrm{R}_{\mathrm{net}}\right)$ by A.sieberi and $2828 \mathrm{kcal}$ $\mathrm{m}^{-2}\left(0.17 \%\right.$ of the $\mathrm{R}_{\text {incoming }}$ and $0.36 \%$ of the $\left.R_{n e t}\right)$ by A.aucheri. Totally, A.sieberi consumed $0.13 \%$ of the annual $\mathrm{R}_{\text {incoming }}$ and $0.28 \%$ of $\mathrm{R}_{\text {net }}$, and A.aucheri consumed $0.25 \%$ of $\mathrm{R}_{\text {incoming }}$ and $0.54 \%$ of $\mathrm{R}_{\text {net }}$, in both GPP and transpiration respectively.

\section{Discussion}

Desert and semidesert shrublands represent approximately 18 million $\mathrm{km}^{2}$ of land area worldwide (Whittaker, 1975). The communities of Artemisia sieberi and Artemisia aucheri are two of the most widespread vegetation covers in arid and semiarid shrublands of central parts of Iran. These communities play an important role in carbon dioxide absorption and carbon sequestration. There is little information on the rate of GPP in arid and semiarid shrublands throughout the world, and no study has been done in this area on Artemisia communities in Iran. The total biomass of A.sieberi was $36 \%$ of A.aucheri. This may result form a more favorable climatic condition in A.aucheri stand. The total NPP of A.sieberi (32.11 $\mathrm{g} \mathrm{C} \mathrm{m}^{-2} \mathrm{yr}^{-1}$ ) and A.aucheri $\left(62.75 \mathrm{~g} \mathrm{C} \mathrm{m}^{-2} \mathrm{yr}^{-1}\right)$ was found to be less than that of forest ecosystems (e.g., $307 \mathrm{~g} \mathrm{C} \mathrm{m}^{-2} \mathrm{yr}^{-1}$ for Picea mariana in boreal forests, Ryan et al., 1997; $960 \mathrm{~g} \mathrm{C} \mathrm{m}^{-2} \mathrm{yr}^{-1}$ for Pinus radiata in temperate coniferous forests, Arneth et al., 1998; $817 \mathrm{~g} \mathrm{C} \mathrm{m}^{-2} \mathrm{yr}^{-1}$ for Betula ermanii, B, platyphylla and Quercus mongolia in temperate deciduoud forests, Saigusa et al., 2002, $1560 \mathrm{~g} \mathrm{C} \mathrm{m}^{-2} \mathrm{yr}^{-1}$ in tropical forests, Malhi et al., 1999) and temperate grasslands (e.g., 1207 and $1140 \mathrm{~g} \mathrm{C} \mathrm{m}^{-2} \mathrm{yr}^{-1}$ in a Miscanthus sinensis grassland in Japan over a 2-year period, Yazaki et al., 2004). The amount of NPP for Artemisia was found to be approximately close to NPP in some desert grasslands and shrublands (e.g., aboveground NPP: $51.1 \mathrm{~g} \mathrm{C} \mathrm{m}^{-2} \mathrm{yr}^{-1}$ in a Bouteloua eriopoda grassland and $59.2 \mathrm{~g} \mathrm{C} \mathrm{m}^{-2}$ $\mathrm{yr}^{-1}$ in a Larrea tridentata shrubland in northern chihuahuan desert, USA, Muldavin et al., 2008). However above ground NPP is reported $224.09 \mathrm{~g} \mathrm{~m}^{-2}$ in a desert shrubland of Artemisia ordosica in Mongolia, China, with an annual precipitation of $345.2 \mathrm{~mm}$ (Zhao et al., 2007). The low NPP of Artemisia species likely relates to a deficiency of rainfall, a short period of favorable climatic condition (rainfall is available only in two months, March through April, during the growing season) and a low LAI. A.sieberi NPP was approximately half of the A.aucheri NPP. This is a consequence of the lower precipitation in A.sieberi site. Studies have highlighted that NPP increases greatly with 
increasing precipitation at precipitations below around $4000 \mathrm{~mm} \mathrm{yr}^{-1}$ (Lieth, 1975) or $2200 \mathrm{~mm} \mathrm{yr}^{-1}$ (Schuur, 2003). The annual GPP $\left(\mathrm{g} \mathrm{C} \mathrm{m}^{-2} \mathrm{yr}^{-1}\right)$ of A.sieberi (85.21) and A.aucheri (154.31) was low in compared to GPP estimates in temperate grasslands (e.g., 584 and $1112 \mathrm{~g} \mathrm{C} \mathrm{m}^{-2} \mathrm{yr}^{-1}$ in a semiarid grassland in Hungary in a dry and wet condition, respectively, Nagy et al., 2007) and forest ecosystems (e.g., $3 \mathrm{~kg} \mathrm{C} \mathrm{m}^{-2} \mathrm{yr}^{-1}$ in tropical forests, Chambers et al., 2000; $1.1 \mathrm{~kg} \mathrm{C} \mathrm{m}^{-2} \mathrm{yr}^{-1}$ for Picea mariana in boreal forests, Ryan et al., 1997; $1.6 \mathrm{~kg} \mathrm{C} \mathrm{m}^{-2} \mathrm{yr}^{-1}$ for Pinus strobes and Acer rubrum in temperate mixed forests, Curtis et al., 2005). The high GPP in forests and temperate grasslands is likely related to year-round growing season, fertile soils and a high LAI (Giardina et al., 2003). The ratio of NPP/GPP refereed to as carbon use efficiency (CUE) was 0.38 for A.sieberi and 0.41 for A.aucheri. This indicates that NPP is approximately proportional to GPP across the different sites (e.g., in different forest types, Waring et al., 1998; DeLucia et al., 2007). The value of CUE in Artemisia stands in the arid and semiarid study sites was found to be higher than CUE for old boreal forests (0.31) (Ryan et al., 1997), and lower than CUE in temperate deciduous forests (0.59) and the universal value of 0.47 (Waring et al., 1998). Overall, studies suggest that variation in the climate, ecosystem type, species, edaphic factors (Giardina et al., 2003), stand age and leaf mass-to-total mass (DeLucia et al., 2007) may exert a great influence on the value of CUE. The fraction of total NPP allocated belowground (Belowground $\mathrm{NPP} /$ total NPP), as an important factor influencing nutrient and water uptake, C turnover and species composition (Jackson et al., 2000; Obrist and Arnone, 2003), was $8 \%$ greater for A.aucheri (0.37) than that for A. sieberi (0.29). This is in contrast with the statement that BNPP to total NPP decreases with increasing precipitation (e.g., Runyon et al., 1994; Hui and Jackson, 2005). Hui and Jackson (2005) synthesizing biomass data at 12 grassland sites around the world reported that the ratio of BNPP to total NPP decreases with increasing mean annual precipitation and temperature. Mean annual precipitation in the A.aucheri study site is $38 \%$ higher than A.sieberi study site and mean annual temperature is $19 \%$ lower than A.sieberi study site. Generally BNPP is strongly influenced by climatic factors (Schuur, 2003). Several studies have shown that there is a positive relationship between BNPP and precipitation (Bradford et al., 2006; Gao et al., 2010), but a negative relationship between BNPP and temperature (Bradford et al., 2006; De Boeck et al., 2007). These results are likely a consequence of the fact that higher precipitation increases water availability whereas higher temperature decreases water availability. It seems that in order to balance the water demand of the transpiring leaf surface with the water uptake capacity of the root system (Gao et al., 2010), a greater amount of NPP was allocated to belowground components in the A.aucheri site in a reaction to a higher precipitation and a lower temperature. Respiration was approximately $60 \%$ of GPP for both species. This is in line with the statement that partitioning to respiration is constant across a wide range of GPP (Waring et al., 1998; Gifford, 2003) and does not vary with resource availability and competition (Ryan et al., 2004). However, the ratio of belowground respiration to GPP for A.aucheri (0.41) was greater than that for A.sieberi (0.29). The higher ratio of belowground respiration to GPP for A.aucheri results from both a greater allocation of total NPP to BNPP and a higher belowground biomass to total biomass for A.aucheri. The percentage of the incoming and net solar energy absorbed in photosynthesis (as GPP) by A.sieberi $(0.047 \%, 0.1 \%)$ and by A.aucheri $(0.084 \%, 0.18 \%)$ showed that the conversion efficiency of solar energy to GPP by shrubs in arid and semiarid climates is low in compared to croplands (e.g., cornfield: $1.6 \%$; Transeau, 1926; maize field: 1.2 
$\%$, Ovington and Lawrence, 1967; rice-barley: $0.89 \%$, groundnuts-wheat: $0.95 \%$ and maize-Lolium multiflorum double cropping agro-ecosystems: $2.4 \%$, Koizumi et al., 1990), grass communities (e.g., $1.2 \%$, Golley, 1960; C3 grass:2.4 \% and C4 grass: 3.7\%, Piedade et al., 1991; Beale and Long, 1995) and forests (e.g., 1\%, Droste, 1979). Maximum conversion efficiency of solar energy to biomass is reported $4.6 \%$ for $\mathrm{C} 3$ and $6 \%$ for C4 photosynthesis (Zhu et al., 2008). The causes in the energy loss at the discrete steps of the plant photosynthetic process from interception of radiation to the formation of stored chemical energy in biomass include: outside photosynthetically active spectrum, reflected and transmitted radiation, photochemical inefficiency, photorespiration and respiration (Zhu et al., 2008). The percentage of the incoming and net solar energy used in transpiration by A.sieberi and A.aucheri was dependant on the amount of both rainfall and temperature. An increase in the amount of both precipitation and temperature may result in a higher evapotranspiration, productivity, LAI and as a result in an increase in the amount of solar energy used in transpiration by plants. To expand the ecosystem services and functions such as carbon dioxide absorption, forage production, climate regulation, etc, in arid ecosystems it is necessary to improve the primary production of species. Establishment and maintenance and of a variety of plant species in arid and semiarid ecosystems, specially a mixture of shrub and grass forms (Mousaei Sanjerehei et al., 2011) may result in a greater aboveground productivity in compared to pure species stands (Forrester et al., 2006; Bessler et al., 2009).

\section{REFERENCES}

[1] Allen, R.G., Pereira., L.S., Raes, D., Smith, M. (1998): Crop evapotranspiration Guidelines for computing crop water requirements. - FAO Irrigation and drainage paper 56.

[2] Amthor, J.S. (1989): Respiration and crop productivity. - Springer-Verlag, New York, pp. 215.

[3] Arneth, A., Kelliher, F.M., McSeveny, T.M., Byers, J.N. (1998): Net ecosystem productivity, net primary productivity and ecosystem carbon sequestration in a Pinus radiata plantation subject to soil water deficit. - Tree Physiology 18: 785-793.

[4] Beale, C.V., Long, S.P. (1995): Can perennial C4 grasses attain high efficiencies of radiant energy-conversion in cool climate. - Agric Forest Meteorol 96: 103-115.

[5] Bessler, H., Temperton, V.M., Roscher, C., Buchmann, N., Schmid, B., Schulze, E.D., Weisser, W.W., Engels, C. (2009): Aboveground over yielding in grassland mixtures is associated with reduced biomass partitioning to belowground organs. - Ecology 90: 1520-1530.

[6] Bradford, J.B., Lauenroth, W.K., Burke, I.C., Paruelo, J.M. (2006): The Influence of Climate, Soils, Weather, and Land Use on Primary Production and Biomass Seasonality in the US Great Plains. - Ecosystems 9: 934-950.

[7] Campbell, G.S. (1985): Soil physics with basic transport models for soil-plant systems. Developments in Soil Science 14, Elsevier, New York.

[8] Chambers, J.Q., Santos, J., Ribeiro, R.J., Higuchi, N. (2000): Tree damage, allometric relationships, and above-ground net primary production in central Amazon forest. Forest Ecology and Management 5348: 1-12.

[9] Chiariello, N.R., Mooney, H.A., Williams, K. (1989): Growth, carbon allocation and cost of plant tissues, p. 327-365. - In: Pearcy, R.W., Ehleringer,J., Mooney, H.A., Rundel, P.W. (eds) Plant physiological ecology. Field methods and instrumentation Chapman and Hall, N.Y. 
[10] Curtis, P.S., Vogel, C.S., Gough, C.M., Schmid, H.P., Su, H.B., Bovard, B.D. (2005): Respiratory carbon losses and the carbon-use efficiency of a northern hardwood forest, 1999-2003. - New Phytologist 167: 437-456.

[11] De Boeck, H.J., Lemmens, C.M.H.M., Gielen, B., Bossuyt, H., Malchair, S., Carnol, M., Merckx, R., Ceulemans, R. Nijs, I. (2007): Combined effects of climate warming and plant diversity loss on aboveand below-ground grassland productivity. - Environmental and Experimental Botany 60: 95-104.

[12] DeLucia, E.H., Drake, J.E., Thomas, R.B., Gonzalez-Meler, M. (2007): Forest Carbon Use Efficiency: Is Respiration a Constant Fraction of Gross primary production? - Global Change Biology 13: 1157-1167.

[13] Droste, B.V. (1979): Forsts biomass for energy. Keynote address. Biological and sociological basis for a rational use of forest resources for energy and organics: An International Workshop. - Michigan State University East Lansing, Michigan.

[14] Fogel, R. (1983): Root turnover and productivity of coniferous forests. - Plant Soil 71: 75-85.

[15] Forrester, D.I., Bauhus, J., Cowie, A.L. (2006): Carbon allocation in a mixed-species plantation of Eucalyptus globulus and Acacia mearnsii. - For. Ecol. Manage 233: 275284.

[16] Gao, Y.Z., Chen, Q., Lin, S., Giese, M., Brueck, H. (2010): Resource manipulation effects on net primary production, biomass allocation and rain-use efficiency of two semiarid grassland sites in Inner Mongolia, China. - Oecologia 165: 855-864.

[17] Giardina, C.P, Ryan, M.G., Binkley, D., Fownes, J.H. (2003): Primary production and carbon allocation in relation to nutrient supply in a tropical experimental forest. - Global Change Biology 9: 1438-1450.

[18] Gifford, R.M. (2003): Plant respiration in productivity models: conceptualisation, representation and issues for global terrestrial carbon-cycle research. - Functional Plant Biology 30: 171-186.

[19] Golley, F.B. (1960): Energy dynamics of a food chain of an old-field community. Ecological Monographs 30: 187-206.

[20] Harrison, L.P. (1963): Fundamentals concepts and definitions relating to humidity. - In: Wexler, A. (ed.) Humidity and moisture. Vol 3, Reinhold Publishing Co., New York, NY, USA.

[21] Hui, D., Jackson, R.B. (2005): Geographical and interannual variability in biomass partitioning in grassland ecosystems: a synthesis of field data. - New Phytologist 169: 8593.

[22] IPCC - Intergovernmental panel on climate change (1990): Climate Change, the IPCC Scientific Assessment. Report from Working Group I. - Cambridge: Cambridge University Press.

[23] Jackson, R.B., Schenk, H.J., Jobbágy, E.G., Canadell, J., Colello, G.D., Dickinson, R.E., Field, C.B., Friedlingstein, P., Heimann, M., Hibbard, K., Kicklighter, D.W., Kleidon, A., Neilson, R.P., Parton, W.J., Sala, O.E., Sykes, M.T. (2000): Belowground consequences of vegetation change and their treatment in models. - Ecological Applications 10: 470483.

[24] Johnson, F.L., Risser, P.G. (1974): Biomass, annual net primary production, and dynamics of six mineral elements in a post oak-blackjack oak forest. - Ecology 55: 12461258.

[25] Koizumi, H. Usami, Y., Satoh, M. (1990): Annual net primary production and efficiency of solar energy utilization in three double-cropping agro-ecosystems in Japan. Agriculture, Ecosystems and Environment 32: 241-255.

[26] Kurn, D.K., Bretz, S.E., Akbari, H. (1994): The potential for reducing urban air temperatures and energy consumption through vegetative cooling. - In: Proceedings of the 1994 Summer Study on Energy Effects in Buildings, Pacific Grove, California. 
[27] Lieth, H. (1975): Modeling the primary productivity of the world, pages 237-264. - In: Lieth, H., Whittaker, R.H. (ed.) Primary productivity of the biosphere. Springer-Verlag, New York, New York, USA.

[28] Malhi, Y., Baldocchi, D.D., Jarvis, P.G. (1999): The carbon balance of tropical, temperate and boreal forests. - Plant, Cell and Environment 22: 715-740.

[29] Meyerson, L.A., Baron, J., Melillo, J.M., Naiman, R.J., O’Malley, R.I., Orians, G., Palmer, M.A., Pfaff, A.S.P., Running, S.W., Sala, O.E. (2005): Aggregate measures of ecosystem services: Can we take the pulse of nature? - Front. Ecol. Environ 3: 56-59.

[30] Mousaei Sanjerehei, M., Jafari, M., Mataji, A., Baghestani Meybodi, N., Bihamta, M.R. (2011): Facilitative and competitive interactions between plant species (an example from Nodushan rangelands, Iran). - Flora 206: 631-637.

[31] Muldavin, E.H., Moore, D.I., Collins, S.L., Wetherill, K.R., Lightfoot, D.C. (2008): Aboveground net primary production dynamics in a northern Chihuahuan Desert ecosystem. - Oecologia 155:123-132.

[32] Nagy, Z., Pinter, K., Czobel, Sz., Balogh, J., Horvath, L., Foti, Sz., Barcza, Z., Weidinger, T., Csintalan, Zs., Dinh, N.Q., Grosz, B., Tuba, Z. (2007): The carbon budget of semi-arid grassland in a wet and a dry year in Hungary. - Agriculture, Ecosystems and Environment 121: 21-29.

[33] Obrist, D., Arnone, J.A., III. (2003): Increasing $\mathrm{CO}_{2}$ accelerates root growth and enhances water acquisition during early stages of development in Larrea tridentata. New Phytologist 159: 175-184.

[34] Ovington, J.D., Lawrence, D.B. (1967): Comparative chlorophyll and energy studies of prairie, savanna, oakwood, and maize field ecosystems. - Ecology 48: 515-524.

[35] Penning De Vries, F.W.T. (1975): The cost of maintenance processes in plant cells. Ann. Bot. 39: 77-92.

[36] Piedade, M.T.F, Junk, W.J., Long, S.P. (1991): The productivity of the C4 grass Echinochloa polystachya on the Amazon floodplain. - Ecology 72: 1456-1463.

[37] Poorter, H. (1994): Construction costs and payback time of biomass: a whole plant perspective. - In: A Whole Plant Perspective on Carbon-Nitrogen Interactions. Roy, J., Garnier, E. (ed.), SPB Academic Publishing, The Hague, pp. 111-127.

[38] Roxburgh, S.H., Barrett, D.J., Berry, S.L., Carter, J.O., Davies, I.D., Gifford, R.M., Kirschbaum, M.U.F., McBeth, B.P., Noble, I.R., Parton, W.G., Raupach, M.R. Roderick, M.L. (2004): A critical overview of model estimates of net primary productivity for the Australian continent. - Funct. Plant Biol 31: 1043-1059.

[39] Roy, J., Saugier, B. (2001): Terrestrial primary productivity: definitions and milestones. In: Terrestrial Global Productivity. Roy, J., Saugier, B., Mooney, H.A. (ed.) Academic Press, San Diego, pp 1-6.

[40] Runyon, J., Waring, R.H., Goward, S.N., Welles, J.M. (1994): Environmental limits on above-ground production: observations from the Oregon transect. - Ecological Applications 4: 226-237.

[41] Ryan, M.G. (1991): A simple method for estimating gross carbon budgets for vegetation in forest ecosystems. - Tree Physiology 9: 255-266.

[42] Ryan, M.G., Binkley, D., Fownes, J.H., Giardina, C.P., Senock, R.S. (2004): An experimental test of the causes of forest growth decline with stand age. - Ecological Monographs 74: 393-414.

[43] Ryan, M.G., Lavigne, M.B., Gower, S.T. (1997): Annual carbon cost of autotrophic respiration in boreal forest ecosystems in relation to species and climate. - Journal of Geophysical Research 102: 28871-28883.

[44] Ryan, M.G., Waring, R.H. (1992): Maintenance respiration and stand development in a subalpine lodgepole pine forest. - Ecology 73: 2100-2108.

[45] Saigusa, N.S., Yamamoto, S., Murayama, S., Kondo, H., Nishimura, N. (2002): Gross primary production and net ecosystem exchange of a cool-temperate deciduous forest 
estimated by the eddy covariance method. - Agricultural and Forest Meteorology 112: 203-215.

[46] Schlapfer, F., Schmid, B. (1999): Ecosystem effects of biodiversity: A classification of hypotheses and exploration of empirical results. - Ecol. Appl. 9: 893-912.

[47] Schreiber, P. (1904): Uber die Beziehungen zwischen dem Niederschlag und der Wasserfuhrung der Flusse in Mitteleuropa. - Z. Meteorol. 21: 441- 452.

[48] Schuur, E.A.G. (2003): Productivity and global climate revisited: the sensitivity of tropical forest growth to precipitation. - Ecology 84: 1165-1170.

[49] Thornthwaite, C.W. (1948): An approach toward a rational classification of climate. Geographical Review 38: 55-94.

[50] Transeau, E.N. (1926): The accumulation of energy by plants. - Ohio J. Sci. 26: 1-10.

[51] Vertregt, N., Penning de Vries, F.W.T. (1987): A rapid method for determining the efficiency of biosynthesis of plant biomass. - J. Theor. Biol. 128: 109-119.

[52] Waring, R.H., Landseberg, J.J., Williams, M. (1998): Net primary production of forests: a constant fraction of gross primary production? - Tree Physiology 18: 129-113.

[53] Whittaker, R.H. (1975): Communities and ecosystems. $-2^{\text {nd }}$ ed., New York, The Macmillan Co.

[54] Williams, K., Percival, F., Merino. J., Mooney, H.A. (1987): Estimation of tissue construction cost from heat of combustion and organic nitrogen content. - Plant, Cell Environ. 10: 725-734.

[55] Yazaki, Y., Mariko, S., Koizumi, H. (2004): Carbon dynamics and budget in a Miscanthus sinensis grassland in Japan. - Ecological Research 19: 511-520.

[56] Zhao, J., Yu-chun, Q., Yun-she, D. (2007); Storage of biomass and net primary productivity in desert shrubland of Artemisia ordosica on Ordos Plateau of Inner Mongolia, China. - Journal of Forestry Research 18: 298-300.

[57] Zhu, X., Long, S.P., Ort, D.R. (2008): What is the maximum efficiency with which photosynthesis can convert solar energy into biomass? - Current Opinion in Biotechnology 19: 153-159. 